\title{
Effects of Stellera chamaejasme removal on the nutrient stoichiometry of $S$. chamaejasme-dominated grasslands in the Qinghai-Tibetan plateau
}

\author{
Meiling Song ${ }^{\text {Corresp., } 1}$, Yuqin Wang ${ }^{1}$, Gensheng Bao ${ }^{1}$, Hongsheng Wang ${ }^{1}$, Yali Yin ${ }^{1}$, Xiuzhang Li ${ }^{1,2}$, Chunping Zhang \\ ${ }^{1}$ Qinghai Academy of Animal and Veterinary Sciences, State Key Laboratory of Plateau Ecology and Agriculture, Qinghai University, Xining, Qinghai, China \\ 2 State Key Laboratory of Grassland Agro-ecosystems, SKLGAE, Lanzhou University, Lanzhou, Gansu, China \\ Corresponding Author: Meiling Song \\ Email address: meilings@163.com
}

Background. Stoichiometric relations drive powerful constraints in several fundamental ecosystem processes. However, limited studies have been conducted on the ecological stoichiometry of plants after the change of community composition induced by S. chamaejasme removal in alpine grassland in the Qinghai-Tibetan Plateau.

Methods. We investigated the effects of $S$. chamaejasme removal on ecological stoichiometry by estimating the $\mathrm{C}: \mathrm{N}: \mathrm{P}$ stoichiometry in species, functional group, and community levels of the ecosystem. The interactions between different species, functional groups, and correlation with soil nutrient, responding to $S$. chamaejasme removal were also analyzed.

Results. For the plants that became dominant after S. chamaejasme removal (SR), N content decreased and their $\mathrm{C}: \mathrm{N}$ increased. S. chamaejasme removal significantly affected the nutrient stoichiometry of different functional groups. Specifically, Gramineae in the SR sites had decreased N content and N:P, and increased $\mathrm{C}: \mathrm{N}$; however, forbs had increased $\mathrm{N}$ content, $\mathrm{C}: \mathrm{P}$, and $\mathrm{N}: \mathrm{P}$, and decreased $\mathrm{P}$ content and $\mathrm{C}: \mathrm{N}$. At the community level, $\mathrm{N}$ content was lower and $\mathrm{C}: \mathrm{N}$ higher in $\mathrm{SR}$ communities compared to $\mathrm{CK}$. The $\mathrm{N}$ content of the plant community was positively correlated with soil total $\mathrm{N}$ content.

S. chamaejasme removal could change the nutrient balance from species level, to functional group level, and to community level. Thus, supplementary measures might be cooperated with $S$. chamaejasme removal for the recovery of $S$. chamaejasme-dominated degraded grassland. These results provide insight into the role of $S$. chamaejasme in ecological protection and conservation, and the conclusions from this study could be used to develop effective and sustainable measures for $S$. chamaejasme control in the Qinghai-Tibetan Plateau. 
1 Effects of Stellera chamaejasme removal on the nutrient stoichiometry of $\boldsymbol{S}$. chamaejasme2 dominated grasslands in the Qinghai-Tibetan Plateau

3 Meiling Song ${ }^{1}$, Yuqin Wang ${ }^{1}$, Gensheng Bao ${ }^{1}$, Hongsheng Wang ${ }^{1}$, Yali Yin ${ }^{1}$, Xiuzhang Li ${ }^{1,}$, 4 Chunping Zhang ${ }^{1}$

$5{ }^{1}$ Qinghai Academy of Animal and Veterinary Sciences, State Key Laboratory of Plateau Ecology 6 and Agriculture, Qinghai University, Xining, Qinghai, China

$7 \quad 2$ State Key Laboratory of Grassland Agro-ecosystems, SKLGAE, Lanzhou University, Lanzhou, 8 Gansu, China

9 Corresponding Author:

10 Meiling Song ${ }^{1}$

11 Email address: meilings@163.com 
12

13

14

\section{Abstract}

Background. Stoichiometric relations drive powerful constraints in several fundamental ecosystem processes. However, limited studies have been conducted on the ecological stoichiometry of plants after the change of community composition induced by $S$. chamaejasme removal in alpine grassland in the Qinghai-Tibetan Plateau.

Methods. We investigated the effects of S. chamaejasme removal on ecological stoichiometry by estimating the $\mathrm{C}: \mathrm{N}: \mathrm{P}$ stoichiometry in species, functional group, and community levels of the ecosystem. The interactions between different species, functional groups, and correlation with soil nutrient, responding to $S$. chamaejasme removal were also analyzed.

Results. For the plants that became dominant after $S$. chamaejasme removal (SR), N content decreased and their C:N increased. S. chamaejasme removal significantly affected the nutrient stoichiometry of different functional groups. Specifically, Gramineae in the SR sites had decreased $\mathrm{N}$ content and $\mathrm{N}: \mathrm{P}$, and increased $\mathrm{C}: \mathrm{N}$; however, forbs had increased $\mathrm{N}$ content, $\mathrm{C}: \mathrm{P}$, and $\mathrm{N}: \mathrm{P}$, and decreased P content and C:N. At the community level, N content was lower and C:N higher in SR communities compared to $\mathrm{CK}$. The $\mathrm{N}$ content of the plant community was positively correlated with soil total $\mathrm{N}$ content.

S. chamaejasme removal could change the nutrient balance from species level, to functional group level, and to community level. Thus, supplementary measures might be cooperated with $S$. chamaejasme removal for the recovery of $S$. chamaejasme-dominated degraded grassland. These results provide insight into the role of $S$. chamaejasme in ecological protection and conservation, and the conclusions from this study could be used to develop effective and sustainable measures for S. chamaejasme control in the Qinghai-Tibetan Plateau.

Keywords Stellera chamaejasme, plant removal, nutrient stoichiometry, Qinghai-Tibetan Plateau, toxic weed 


\section{Introduction}

Ecological stoichiometry is used to examine the relationships between organisms and ecosystem structure and function, and reflects the dynamic balance of multiple key element, most carbon (C), nitrogen $(\mathrm{N})$ and phosphorus (P), in ecological system (Elser et al., 1996; Elser et al., 2000; Sterner \& Elser, 2002). C:N:P stoichiometry plays an important role in key ecological processes, including but not limited to, plant-herbivore-predator relationships (Kagata \& Ohgushi, 2006; Tibbets \& Molles, 2005), ecosystem-specific composition and diversity (Güsewell et al., 2005; Olde Venterink et al., 2003), and the capacity of a system to adapt to environmental stress (Sardans et al., 2008; Sardans, Rivas-Ubach \& Peñuelas, 2012; Song et al., 2015). Many studies have shown that stoichiometric ratios at species-level are sensitive to global change drivers, such as nitrogen deposition, alteration of precipitation regime, and so on (Henry et al., 2006; Lü et al., 2012; Lü et al., 2018). Many plant species with various nutrient characteristics coexist in most natural ecosystems (Hou et al., 2019; Lü and Han, 2010). The responses of community-level nutrient status is simultaneously governed by variation at individual species or functional group level and alteration of community composition, as well as co-variation between them (Hu et al., 2020; Lepš et al. 2011). Stoichiometric homeostasis describes the capacity of an organism or ecosystem to maintain its internal elemental balance regardless of resource supply (Borer et al., 2015; Sterner \& Elser, 2002); therefore, it is crucial to examine C:N:P stoichiometry at not only the species level but also at the community level.

Plant stoichiometric traits can be influenced by its neighboring species and the richness of the ecosystem (Abbas et al., 2013; Borer et al., 2015; Guiz et al., 2018). Because there is a wide diversity in innate characteristics between plant species, such as life-history, physiology, and tissue chemistry, each has a unique influence on $\mathrm{C}, \mathrm{N}$, or $\mathrm{P}$ cycling and their stoichiometry in an ecosystem (Ehrenfeld, 2003; Eviner, 2004; Scott, Saggar \& McIntosh, 2001). Previous studies in high altitude grasslands have found that net plant-plant interactions will shift from competitive to facilitative in response to environmental change (Bret-Harte et al., 2004; Callaway et al., 2002). While plants with different life strategies will compete for limited resources (water, light, and 
63

64

nutrients), they may also acquire facilitative shelter from their neighbors against severe climatic events such as solar radiation, strong winds, and low temperature in alpine grasslands (Klanderud \& Totland, 2005; Wang et al., 2008). Changes in community traits could be weighted by species relative abundance, which are more driven by dominant species rather than subdominant species in community (Violle et al., 2012; Hou et al., 2019).Thus, any changes in community composition would have implications for the changes of community level nutritional traits (Lü et al., 2018). On the other hand, many studies have reported that the species-specific interactions have influence on plant growth and community composition (Callaway et al., 2002; Wang et al., 2008). However, there has this far been little attention paid to the potential impacts of species on the nutrient cycling processes in alpine grasslands at all levels from species to functional group and community.

Aside from their innate characteristics, plants can influence $\mathrm{C}, \mathrm{N}$, and $\mathrm{P}$ cycling and stoichiometry by modifying the biomass, composition and/or activity of the soil microbial community (Bezemer et al., 2006; Ehrenfeld, 2003; Groffman et al., 1996; Sun et al., 2009). Stellera chamaejasme is a toxic perennial weed found in the eastern alpine grassland of the Qinghai-Tibetan Plateau (QTP) of China. S. chamaejasme has become a dominant species, especially in heavily-grazed grassland, and can seriously threaten alpine grassland productivity and ecological sustainability (Liu, Long \& Yao, 2004; Xing \& Song, 2002). Thus, many research studied on S. chamaejasme exclusion and control for degraded grassland recovery (Song et al., 2018; Wang et al., 2018). S. chamaejasme spreads for many reasons including toxicity to livestock preventing its consumption (Liu, Long \& Yao, 2004), its allelopathic effects on forages (Zhou, Huang \& A, 1998), and its association with creating "fertility islands", which enable greater soil nutrient availability (Guo \& Wang, 2018; Sun et al., 2009). Hence, S. chamaejasme may induce the changes of soil nutrient or growth of other species. Although the effect of removal on plant communities has been reported, the effects on $\mathrm{C}, \mathrm{N}$, and P community stoichiometry have not been studied before. The information resulting from this research might aid in understanding this species role in ecological protection and conservation in alpine grasslands.

Empirical and theoretical evidence shows that a species change would affect the community 
90

91

composition, and any changes in community composition would have implications for the community level nutritional traits (Callaway et al., 2002; Hou et al., 2019; Lü et al., 2018). We hypothesized that $S$. chamaejasme removal would induce different changes of C:N:P stoichiometry of plants from species level to functional group level, and to community level. Sun et al. (2009) reported that $S$. chamaejasme promoted its expansion through creating islands of fertility, which had higher $\mathrm{N}$ availability and turnover rates in $S$. chamaejasme patches soils. We further hypothesized that the concentration of $\mathrm{N}$ in community plants might be promoted by the higher soil $\mathrm{N}$ availability after $S$. chamaejasme removal.

\section{Materials \& Methods}

Study site

The study was conducted in an alpine grassland at an elevation of 3,230 $\mathrm{m}$ in Haiyan County (N $37^{\circ} 04^{\prime}$, E $100^{\circ} 52^{\prime}$ ), approximately $125 \mathrm{~km}$ northwest of Xining, capital city of the Qinghai Province, China. This area has a typical plateau continental climate, with a mean annual solar radiation of $2,580 \mathrm{~h}$, mean annual temperature of 0.4 to $3.4{ }^{\circ} \mathrm{C}$, and annual precipitation of 277.8 to $499.5 \mathrm{~mm}$ (most of which falls between May and September). Vegetation is typical of an alpine grassland, with Kobresia and Elymus species being the dominant plants in our study area. Other companion species included Festuca ovina, Poa pratensis, Melissitus ruthenica, Kobresia humilis, Carex atrofusca and Lancea tibetica. Local herders use the study site as a winter rangeland (grazing from September to May) with a heavy grazing intensity of about 7.94 sheep units per hm². Within the last few decades, $S$. chamaejasme has invaded the grassland and gradually become the dominant species in the study area resulting in the grassland facing serious degradation challenges. Field experiments were approved by the Haiyan County Grassland Station, Haibei, Qinghai (approval number: 2016-NK-136).

\section{Experimental design}

Given that the different topographical distribution, the experimental plots were arranged as a randomized blocked design with three blocks $(40 \mathrm{~m} \times 60 \mathrm{~m}$ in size $)$ located along the drainage 
116

117

118

119

120

121

122

123

124

125

126

127

128

129

130

131

132

133

134

135

136

137

138

139

140

141

gradient, in May 2016. Each block was 30 - 40 m apart. In each block, two treatments (Control, $\mathrm{CK}$; S. chamaejasme removal, SR) were established with four replicate plots $(20 \mathrm{~m} \times 7 \mathrm{~m}$ in size $)$, resulting in a total of 12 plots for CK and SR respectively. In SR, S. chamaejasme were artificially removed by pulling out in June 2016, and the soil which had been carried out was returned to the original site immediately. Plots were monitored weekly during the growing season to ensure there was no further S. chamaejasme growth.

\section{Plant sampling and chemical analysis}

For species level, Elymus nutans, Poa crymophila, Koeleria litvinowii, Festuca ovina, Stipa aliena, Kobresia capillifolia, Kobresia humilis, and Carex atrofusca, which had a relative coverage of over $80 \%$, were chosen to investigate the influence of $S$. chamaejasme removal on the species C:N:P stoichiometry. At the beginning of August 2017, 30 consistent leaves of each species were collected in each plot, and all leaves collected from 4 plots in a block were pooled as one sample, respectively. Thus, each treatment had three replications in total. For the functional group level, three quadrats $(0.5 \mathrm{~m} \times 0.5 \mathrm{~m})$ were randomly placed in each plot, and, in each quadrat, the leaves of all species were sampled and sorted into four functional groups (Gramineae, sedges, legumes and forbs). Similarly, all leaves collected from 4 plots in each block were pooled as one sample. For the community level, another three quadrats were randomly surveyed in each plot, and the leaves of all species were collected and pooled as one sample in each block. After sampling, all collected leaves were oven dried at $85^{\circ} \mathrm{C}$ to a constant mass, and then ground for further nutrient analysis in the laboratories in Xining, Qinghai University. Soil samples were collected with a soil auger at five random sites in each plot, then the soil samples collected from 4 plots of each block were pooled into one sample with a separation of $0-10 \mathrm{~cm}$ soil depth and $10-20 \mathrm{~cm}$ soil depth. Soil samples were passed through a $1 \mathrm{~mm}$ sieve after air-drying to analyze nutrient content.

The total soil and plant organic $\mathrm{C}$ content was determined using the oil bath- $\mathrm{K}_{2} \mathrm{CrO}_{7}$ titration method - oxidization with dichromate in the presence of $\mathrm{H}_{2} \mathrm{SO}_{4}$, heated at $180{ }^{\circ} \mathrm{C}$ for 5 minutes and titration with $\mathrm{FeSO}_{4}(\mathrm{Bao}, 1999)$. The total $\mathrm{N}$ content of the soil and plant samples following 
142 a Kjeldahl digestion was assayed using a Nitrogen Analyzer System (Kjeltec 2300 Auto System

143

144 II, Foss Tecator AB, Höganäs, Sweden), using $\mathrm{H}_{2} \mathrm{SO}_{4}$ for digestion, $\mathrm{NH}_{3}$ was captured by $\mathrm{H}_{3} \mathrm{BO}_{3}$ and then titrated by $\mathrm{HCl}$. Total $\mathrm{P}$ content was determined using the molybdate blue colorimetric method using a spectrophotometer (SP-723; Shanghai, China) after digestion with $\mathrm{H}_{2} \mathrm{SO}_{4}$ and $\mathrm{H}_{2} \mathrm{O}_{2}$. The levels of $\mathrm{NH}_{4}{ }^{+}-\mathrm{N}$ and $\mathrm{NO}_{3}{ }^{-}-\mathrm{N}$ in the soil samples were measured using a FIAstar 5000 Analyzer FOSS TECATOR. The available P content of the soil was analyzed according to soil agricultural chemistry methods (Bao, 1999). Stoichiometric ratios (C:N, C:P and N:P) in plant were calculated on mass basis.

\section{Statistical analysis}

Data analyses were performed using SPSS (version 17.0). For each plant sample, the C, N and $\mathrm{P}$ content were measured twice, thus mean values in the text are averages of six replications $\pm \mathrm{SE}$. Two-way ANOVA was used to determine the effects of either species and treatments, or functional groups and treatments on $\mathrm{C}, \mathrm{N}$, and $\mathrm{P}$ levels, on the ratios of $\mathrm{C}: \mathrm{N}, \mathrm{C}: \mathrm{P}$, and $\mathrm{N}: \mathrm{P}$, and transformed data was used, when necessary, to satisfy the assumptions of ANOVA. Independent t-tests were used to calculate significance of differences between CK and S. chamaejasme removal treatments in all parameters. Statistical significance was defined at the $95 \%$ confidence level. A principal component analysis (PCA) to assess the various effects of treatments on $\mathrm{C}, \mathrm{N}$, and $\mathrm{P}$ levels, and the ratios of $\mathrm{C}: \mathrm{N}, \mathrm{C}: \mathrm{P}$, and $\mathrm{N}: \mathrm{P}$ in different species or functional groups were performed. A redundancy analysis (RDA) conducted in CANOCO 5.0 for Windows was utilized to assess variation ordination of community stoichiometry traits (contents of $\mathrm{C}, \mathrm{N}$, and $\mathrm{P}$, ratios of $\mathrm{C}: \mathrm{N}, \mathrm{C}: \mathrm{P}$, and $\mathrm{N}: \mathrm{P}$ ) and soil nutrient levels (contents of Organic $\mathrm{C}$, total $\mathrm{N}$, total $\mathrm{P}, \mathrm{NH}_{4}{ }^{+}-\mathrm{N}, \mathrm{NO}_{3}{ }^{-}-\mathrm{N}$, and available $\mathrm{P}$ in $10-20 \mathrm{~cm}$ deep soil).

\section{Results}

\section{Hierarchical responses of plant stoichiometry}

At species level, total $\mathrm{C}$ content of green leaves varied between species, but no significant difference was found between SR and CK (Fig. 1a, Table 1). In total, the treatment and species 
168

169

170

171

172

173

174

175

176

177

178

179

180

181

182

183

184

185

186

187

188

189

190

191

192

193

194

both had significant impacts on $\mathrm{N}$ content, but only species richness significantly altered $\mathrm{P}$ content (Table 1). Specifically, significantly lower $\mathrm{N}$ contents were observed in the green leaves of $E$. nutans, P. crymophila, K. litvinowii, and S. aliena in SR than CK (Fig. 1c). The total P content of P. crymophila was significantly higher in SR than CK, but for C. atrofusca, the total P content was significantly lower in SR than CK (Fig. 1e). No interaction between the treatment and species was found on the $\mathrm{C}, \mathrm{N}$, and $\mathrm{P}$ content (Table 1). However, species and treatment both significantly affected the $\mathrm{C}: \mathrm{N}, \mathrm{C}: \mathrm{P}$, and $\mathrm{N}: \mathrm{P}$ ratio in this study, except the difference was not significant for treatment on the C:P ratio (Table 1). Species and treatment interacted to affect the N:P ratio. The C:N ratio was elevated in $P$. crymophila, K. litvinowii, $F$. ovina, and $S$. aliena leaves in SR compared to $\mathrm{CK}$, and no significant change was seen in the leaves of the other species (Fig. 1b). The C:P ratio significantly declined in P. crymophila and increased in C. atrofusca in SR compared to $\mathrm{CK}$, and no significant difference was seen in the other species (Fig. 1d). The N:P ratio of $P$. crymophila and K. litvinowii significantly decreased in SR compared to CK (respectively), but no difference was observed in the other species (Fig. 1f).

At the functional group level, total $\mathrm{C}$ content of green leaves varied between groups, but no significant difference was found between SR and CK. There was no significant interaction between groups and treatments in affecting $\mathrm{C}$ content (Fig. 2a, Table 2). Groups had significant impacts on $\mathrm{N}$ and $\mathrm{P}$ content, but only $\mathrm{P}$ content was significantly affected by the treatment. The interaction of groups and treatments was significant for $\mathrm{N}$ and $\mathrm{P}$ content (Table 2). Legume had the highest $\mathrm{N}$ content among all the functional groups, and SR treatment did not significantly affect the $\mathrm{N}$ content of legumes. Total $\mathrm{N}$ content declined significantly in Gramineae but increased significantly in forbs in SR compared to CK (Fig. 2c). Additionally, forbs had a significantly lower P content in SR compared to CK, while no significant difference was seen in Gramineae, sedges, or legumes (Fig. 2e). Groups had significant impacts on $\mathrm{C}: \mathrm{N}$ and $\mathrm{C}: \mathrm{P}$ ratios, but treatments had no significant impact on $\mathrm{C}: \mathrm{N}, \mathrm{C}: \mathrm{P}$ and $\mathrm{N}: \mathrm{P}$. The interaction of groups and treatments was significant for C:N, $\mathrm{C}: \mathrm{P}$ and $\mathrm{N}: \mathrm{P}$ (Table 2). In Gramineae, there was no change in the $\mathrm{C}: \mathrm{P}$ ratio, but the $\mathrm{C}: \mathrm{N}$ significantly increased and the N:P significantly declined in SR compared to CK (Fig. 2b, d, f). In 
195

196

197

198

199

200

201

202

203

204

205

206

207

208

209

210

211

212

213

214

215

216

217

218

219

the leaves of forbs, the $\mathrm{C}: \mathrm{N}$ ratio was significantly lower but the $\mathrm{C}: \mathrm{P}$ and $\mathrm{N}: \mathrm{P}$ ratios were significantly higher in SR compared to CK. There was no significant difference in the C:N, C:P, and $\mathrm{N}: \mathrm{P}$ ratios in leaves of sedges or legumes between SR and CK (Fig. 2b, d, f).

At the community level, SR significantly reduced plant total $\mathrm{N}$ content and increased $\mathrm{C}: \mathrm{N}$ ratio (Fig. 3b, c). There was no significant difference in the other parameters at the community level between SR and CK (Fig. 3a, d, e, f).

\section{Driving factors of plant stoichiometry traits}

The PCA analysis showed that the different species and functional groups all showed varying degrees of changes in their leaf $\mathrm{C}, \mathrm{N}$, and P levels, and $\mathrm{C}: \mathrm{N}, \mathrm{C}: \mathrm{P}$, and N:P ratios between SR and CK (Fig. 4, 5). The first two axes of the PCA account for over $80 \%$ of the variation in species traits across the sites for all eight species, with $P$. crymophila and $K$. litvinowii showing significant differentiation in the first axis (Fig. 4a-h). At the functional group level, all groups besides legumes showed significant differentiation, with S. chamaejasme removal responsible for over $75 \%$ variations for all four functional groups (Fig. 5a-d).

RDA analysis showed that approximately $80 \%$ of the variations had been explained and that S. chamaejasme removal had a significant influence on the plant $\mathrm{N}$ content and C:N ratio (Fig. 6). The content of organic $\mathrm{C}$, total $\mathrm{N}$, and available $\mathrm{P}$ in soil were positively correlated with the $\mathrm{N}$ content of leaves, but negatively correlated with the $\mathrm{C}: \mathrm{N}$ ratio of the community. Total $\mathrm{P}$ content in the soil was positively correlated with the C:P and N:P ratios of the community and negative correlation with leaf $\mathrm{P}$ content.

\section{Discussion}

Our results showed that the responses of nutritional trait to $S$. chamaejasme removal were different at different biological organization levels. This was consistent with our first hypothesis. However, the $\mathrm{N}$ content of the community declined and the $\mathrm{C}: \mathrm{N}$ ratio increased after $S$. chamaejasme removal, which is contrary to our second hypothesis. This may be related to the dilution effects by 
220

221

222

223

224

225

226

227

228

229

230

231

232

233

234

235

236

237

238

239

240

241

242

243

244

245

246

stimulating plant growth of some species (Sardans \& Peñuelas, 2008).

In a terrestrial ecosystem, nutrient availability is one of the most limiting factors of plant growth, and thus nutrient use strategies will help determine plant distribution and dominance (Güsewell et al., 2005). The nutrient contents of green tissues could reflect the efficiency of nutrient utilization. Low nutrient concentrations in green tissues are considered to be an efficient mechanism of nutrient conservation and utilization (Carrera, Sain \& Bertiller, 2000). Sistla and Schimel (2012) showed that a high C content in green tissues led to higher nutrient use efficiency. In our study, nutrient contents and C levels were species-specific (Fig. 1a). The $\mathrm{N}$ content of four species, E. nutans, P. crymophila, K. litvinowii, and S. aliena, decreased and the C:N ratio increased following S. chamaejasme removal (Fig. 1b, c). This result may be explained by the increased dominance of these species (Table S1). According to this, they may have developed a $\mathrm{N}$ storage strategy in response to neighbor removal in which more $\mathrm{N}$ is transported to the reproductive organs during the reproductive growth process or to the roots before the wilt period begins. Therefore, the leaf $\mathrm{N}$ content was maintained at a low level in August (Rong et al., 2015). Tilman (1982) speculated that at the resource competition scale, species with low nutrient element concentrations were more suitable for growing in nutrient poor environments. In our study, the $\mathrm{N}: \mathrm{P}$ ratio of most species (except $P$. crymophila in CK and C. atrofusca in SR) at both the CK and SR sites were lower than the threshold of 10:1 (Güsewell, 2004), suggesting that $\mathrm{N}$ is limited, rather than $P$, in this alpine grassland (Fig. 1f). This could also indicate that these species reach dominance because they have lower $\mathrm{N}$ needs than the others under $\mathrm{N}$ limited conditions. In a $\mathrm{N}$ poor environment, enhancing the efficiency of $\mathrm{N}$ utilization is an important strategy to increase species dominance, and species with lower $\mathrm{N}$ concentrations should have a competitive advantage over other species in N-restricted environments (Fan, Harris \& Zhong, 2016; Tilman, 1997). The $\mathrm{N}: \mathrm{P}$ ratio of P. crymophila in CK and C. atrofusca in SR were between 10 and 20 (Fig. 1f), which indicate that the limitation of $\mathrm{N}$ and $\mathrm{P}$ for these two species might transform because of $S$. chamaejasme removal. This could partly explain the increase in the P content of P. crymophila and the decrease of $\mathrm{P}$ content in $C$. atrofusca after $S$. chamaejasme removal, which may also 
247 indicate the strategy of these species for taking up and incorporating $\mathrm{P}$ element has been 248 influenced. Overall, these results show that plants could change the nutrient utilization strategy in 249 response to $S$. chamaejasme removal.

250

251

252

253

254

255

256

257

258

259

260

261

262

263

264

265

266

267

268

269

270

271

272

273

Differences in nutrient uptake and conservation strategies across growth forms and functional groups have also been previously observed (Aerts, 1996; Yuan \& Chen, 2009). The nutrient element contents in plant leaves are continually affected by the plant's structural features and growth regulation (Baldwin et al., 2006). In Gramineae, the $\mathrm{N}$ content decreased and the C:N ratio increased after $S$. chamaejasme removal (Fig. 2b, c). Thereby, the increase in the biomass of Gramineae may be due to their higher utilization efficiency of $\mathrm{N}$ and is in accordance with the "dilution theory," where nutrient element concentration may be diluted in plant bodies when there is a rapid increase in plant biomass (Fig. S1) (Rong et al., 2015; Sardans \& Peñuelas, 2008). The light:nutrient hypothesis states that the $\mathrm{C}: \mathrm{N}$ ratios of plants are higher in bright environments because of the increased gains in photosynthetic $\mathrm{C}$ at any $\mathrm{N}$ concentration (Sterner et al., 1997; Sterner \& Elser, 2002). Following S. chamaejasme removal in S. chamaejasme-dominated alpine grassland, environmental light levels may increase, therefore, species, such as those in Gramineae, will rapidly increase in biomass and have a lower $\mathrm{C}: \mathrm{N}$ ratio. After $S$. chamaejasme removal, the $\mathrm{N}$ content increased and the $\mathrm{C}: \mathrm{N}$ ratio declined in forbs, which could be explained by the utilization efficiency theory that states that a lower efficiency of $\mathrm{N}$ usage results in less biomass (Fig. S1). This may also be related to the increase of soil extractable inorganic $\mathrm{N}$ content $\left(\mathrm{NH}_{4}{ }^{+}-\mathrm{N}\right.$, for example, Fig. S2) after S. chamaejasme removal (Ehrenfeld, 2003), and it also indicates that the ability of forbs to absorb $\mathrm{N}$, in order to maintain growth and adapt to a more severe environment, has been enhanced. The $\mathrm{P}$ level of an organism is partly driven by the allocation of $\mathrm{P}$ to ribosomal RNA, which is related to the increase in its growth rate (Hessen et al., 2007; Song et al., 2015; Vrede et al., 2004). In our study, the total $\mathrm{P}$ content of forbs decreased after $S$. chamaejasme removal (Fig. 2e), which may be partly explained by the measured decrease of the biomass of the forbs (Fig. S2). This agrees with the Growth Rate Hypothesis (GRH) that a higher plant growth rate is usually accompanied by lower C:N or C:P ratios (Elser et al., 1996; Hessen et al., 2007; 
274 Vrede et al., 2004). Previous studies in natural ecosystems have confirmed that plant biomass 275 growth is limited by leaf N:P ratios (Das, Dang \& Shivananda, 2006; Van Duren \& Pegtel, 2000).

276 The variation of autotrophs in the $\mathrm{C}: \mathrm{N}: \mathrm{P}$ composition ratio has interspecific and intraspecific 277 components. Some analyses of the percentage of $\mathrm{N}$ and $\mathrm{P}$ of photosynthetic biomass showed that

278

279

280

281

282

283

284

285

286

287

288

289

290

291

292

293

294

295

296

297

298

299

300

the $\mathrm{P}$ increased faster than $\mathrm{N}$ in a rapidly growing organism (Elser et al., 2000; Nielsen et al., 1996). This theory was reflected in the Gramineae, which had a faster growth rate and lower N:P ratio after $S$. chamaejasme removal. As for the forbs, the increased N:P ratio may be related to the increased availability of $\mathrm{N}$ in the soil following $S$. chamaejasme removal (Fig. S2). Some studies have shown that $\mathrm{N}$ availability increased the N:P ratio of plants (Güsewell et al., 2005), which may explain the decline of the biomass of forbs after S. chamaejasme removal (Fig. S1).

In most terrestrial ecosystems, $\mathrm{N}$ and $\mathrm{P}$ are the main elements that control plant growth (Aerts \& Chapin, 2000). The stoichiometric ratios of C:N:P in plant leaves and litter in many ecosystems have been widely used as indicators to estimate nutrient limitations on plant growth, primary productivity, and litter decomposition (Güsewell, 2005; Tessier \& Raynal, 2003). Our results showed that the N:P ratio in the alpine grassland community did not change after S. chamaejasme removal (Fig. 3f), which indicates that in a short time $S$. chamaejasme removal has little influence on nutrient limitation in this ecosystem. The average $\mathrm{N}: \mathrm{P}$ ratio at $\mathrm{CK}$ and $\mathrm{SR}$ were both $<10$ and therefore suggest that $\mathrm{N}$ was the limiting nutrient in this alpine grassland. The $\mathrm{N}$ content of the community declined and the C:N ratio increased after $S$. chamaejasme removal (Fig. 3b, c). This may due to the dilution effects by stimulating plant growth of several species. The aboveground biomass at SR was significantly higher than in CK (Fig. S1), indicating that the plants in this community have adapted to $S$. chamaejasme removal by increasing their $\mathrm{N}$ utilization efficiency. A previous study has shown that improving the ability to use an element in the environment where the element is limiting is important for plant growth in nutrient poor soils (Tilman, 1997). The decreases in the $\mathrm{N}$ utilization efficiency of forbs resulted in a decrease in biomass (Fig. S1), which helps to explain the plant community composition changes after S. chamaejasme removal. In this study, plant diversity was shown to significantly decrease after $S$. chamaejasme removal (Table 
301

302

303

304

305

306

307

308

309

310

311

312

313

314

315

316

317

318

319

320

321

322

323

324

325

326

327

$\mathrm{S} 2$ ). Some studies have shown that $\mathrm{N}$ availability increases the body $\mathrm{N}: \mathrm{P}$ ratio and reduces the species diversity of communities (Güsewell et al., 2005; Roem \& Berendse, 2000; Seastedt \& Vaccaro, 2001). Our results showed that there was no significant change in the N:P ratio of the community between CK and SR; however, the available $\mathrm{N}\left(\mathrm{NH}_{4}{ }^{+}-\mathrm{N}\right)$ content of the soil increased (Fig. S2) and the N:P ratio increased significantly after $S$. chamaejasme removal. The decline of community diversity seen in this study may therefore be attributed mainly to the reduction of species richness in the forbs group. From the species level to the functional group level, and then on to the community level, the variation of $\mathrm{N}$ and $\mathrm{P}$ concentrations and $\mathrm{C}: \mathrm{N}: \mathrm{P}$ ratios gradually decreased and stabilized. This may relate to grassland ecosystem stability, where the differences among species are balanced out with a greater number of species in the higher vegetation levels (Fan, Harris \& Zhong, 2016). This implies that the changes of species stoichiometry induced by S. chamaejasme removal may be inhibited by inertia effects in ecosystem level.

It is well known that plants and soil are interdependent (Silva \& Batalha, 2008) and there are an increasing number of reports that show that the nutrient traits of plants cannot be separated from the dynamics of soil nutrient availability (Eskelinen, Stark \& Mannisto, 2009; Li et al., 2014). The occurrence of weeds is highly related to soil properties (Korres et al., 2017; Walter, Chritensen \& Simmelsgaard, 2002). In S. chamaejasme-dominated grasslands, the organic C content in the soil decreased significantly after S. chamaejasme removal (Fig. S2). This result was consistent with previous work. For example, S. chamaejasme increases the organic C content of soil because of the greater plant production and litter input or the higher microbial biomass (Sun et al., 2009). The results of this study showed that the organic C content in soil without $S$. chamaejasme was lower than that with a $S$. chamaejasme community. After $S$. chamaejasme removal, the total N, P, and available P content of the soil decreased (Fig. 5c, e, f). This may be due to the fast growth rate of the grasses, which requires greater $\mathrm{N}$ and $\mathrm{P}$ uptake in the absence of competition from $S$. chamaejasme. The content of $\mathrm{NH}_{4}{ }^{+}-\mathrm{N}$ in soil increased significantly after $\mathrm{S}$. chamaejasme removal (Fig. S2). S. chamaejasme is widely distributed throughout alpine grasslands creating islands of fertility, as determined by greater soil nutrient availability (Sun et al., 2009). Therefore, when $S$. 
328

329

330

331

332

333

334

335

336

337

338

339

340

341

342

343

344

345

346

347

348

349

350

351

352

353

chamaejasme has been removed, the soil nutrients gathered by the plants may be released from these "fertility islands," (Guo \& Wang, 2018; Sun et al., 2009), which was reflected by the change of $\mathrm{NH}_{4}{ }^{+} \mathrm{N}$ content observed in the results. The leaf trait-environment relationship is used to explain and predict the underlying mechanisms of leaf nutrient trait variation, environmental change, and to identify the nutrient limitations in an ecosystem (Güsewell, 2004; Kerkhoff et al., 2005; Zhang et al., 2019).

\section{Conclusions}

Different species and functional groups were shown to have different responses to $S$. chamaejasme removal as seen in their $\mathrm{N}$ and $\mathrm{P}$ levels and $\mathrm{C}: \mathrm{N}, \mathrm{C}: \mathrm{P}$, and $\mathrm{N}: \mathrm{P}$ ratios. The species with higher aboveground biomass or dominance has lower N content (like Gramineae), but the species with lower biomass has higher N content and lower P content (like forbs), after S. chamaejasme removal. On the community level, the $\mathrm{N}$ content was lower and the C:N ratio was higher in $S$. chamaejasme removal site than in control site. Thus, S. chamaejasme removal can cause imbalances in the C:N:P stoichiometric ratio as shown in this ecosystem during the period of experiment, and then change species dominance, composition or diversity of the community. Other measures, like supplementary sowing of dicotyledon species, appropriate grazing at growing season, or fertilization, cooperated with $S$. chamaejasme removal may be better for conservation and preservation of the function and species richness in S. chamaejasme-dominated grassland. This study presents the analysis of results obtained from one year of data collection. More systematic studies need to be carried out in alpine $S$. chamaejasme-dominated grasslands in order to reveal the influence of longer time periods and other factors, such as microorganisms, climate, and grazing, or the impact of other alternative measures such as fertilization and grazing prohibition on the recovery of $S$. chamaejasme-dominated degraded grassland.

\section{Acknowledgments}

The authors would like to thank Zengzeng Yang, Zengtao Qi, and Yan Liu for their help collecting samples and analyzing data. We also thank the editor from MogoEdit for the language 
354

355

356

357

358

359

360

361

362

363

364

365

366

367

368

369

370

371

372

373

374

375

376

modification. At last, we appreciate Dr. Alison Haughton, editor in chief from Weed Research, for the constructive advice on the manuscript during the revising process.

\section{References}

Abbas M, Ebeling A, Oelmann Y, Ptacnik R, Roscher C, Weigelt A, Hillebrand H. 2013. Biodiversity effects on plant stoichiometry. PLoS One 8: e58179 DOI 10.1371/journal.pone.0058179.

Aerts R, Chapin FSIII. 2000. The mineral nutrition of wild plants revisited: a re-evaluation of processes and patterns. Advances in Ecological Research 30:1-67 DOI 10.1016/S00652504(08)60016-1.

Aerts R. 1996. Nutrient resorption from senescing leaves of perennials: are there general patterns? Journal of Ecology 84:597-608 DOI 10.2307/2261481.

Baldwin DS, Rees GN, Mitchell AM, Watson G, Williams J. 2006. The short-term effects of salinization on anaerobic nutrient cycling and microbial community structure in sediment from a freshwater wetland. Wetlands 26:455-464 DOI 10.1672/0277-5212(2006)26.

Bao SD. 1999. Methods for soil and agricultural chemistry. Beijing, Chinese Agricultural Press (in Chinese).

Bezemer TM, Lawson CS, Hedlund K, Edwards AR, Brook AJ, Igual JM, Mortimer SR, Van Der Putten WH. 2006. Plant species and functional group effects on abiotic and microbial soil properties and plant-soil feedback responses in two grasslands. Journal of Ecology 94:893-904 DOI 10.2307/3879581.

Borer ET, Lind EM, Ogdahl EJ, Seabloom EW, Tilman D, Montgomery RA, Kinkel L. 2015. Food-web composition and plant diversity control foliar nutrient content and stoichiometry. Journal of Ecology 103:1432-1441 DOI 10.1111/1365-2745.12461. 
377

378

379

380

381

382

383

384

385

386

387

388

389

390

391

392

393

394

395

396

397

398

399

400

401

Bret-Harte MS, Garcia EA, Sacre VM, Whorley JR, Wagner JL, Lippert SC, Chapin FSII. 2004. Plant and soil responses to neighbour removal and fertilization in Alaskan tussock tundra. Journal of Ecology 92:635-647 DOI 10.2307/3599724.

Callaway RM, Brooker RW, Choler P, Kikvidze Z, Lortie CJ, Michalet R, Paolini L, Pugnaire FI, Newingham B, Aschehoug ET, Armas C, Kikodze D, Cook BJ. 2002. Positive interactions among alpine plants increase with stress. Nature 417:844-848 DOI 10.1038/nature00812.

Carrera A, Sain C, Bertiller M. 2000. Patterns of nitrogen conservation in shrubs and grasses in the Patagonian Monte, Argentina. Plant and Soil 224:185-193 DOI 10.1023/a:1004841917272.

Das K, Dang R, Shivananda TN. 2006. Effect of N, P and K fertilizers on their availability in soil in relation to the Stevia plant (Stevia rebaudiana Bert.). Archives of Agronomy and Soil Science 52:679-685 DOI 10.1080/03650340601033233.

Ehrenfeld JG. 2003. Effects of exotic plant invasions on soil nutrient cycling processes. Ecosystems 6:503-523 DOI 10.2307/3658994.

Elser JJ, Dobberfuhl DR, MacKay NA, Schampel JH. 1996. Organism size, life history, and $\mathrm{N}: \mathrm{P}$ stoichiometry. Bioscience 46:674-684 DOI 10.2307/1312897.

Elser JJ, Sterner RW, Gorokhova E, Fagan WF, Markow TA, Cotner JB, Harrison JF, Hobbie SE, Odell GM, Weider LJ. 2000. Biological stoichiometry from genes to ecosystems. Ecology Letters 3:540-550 DOI 10.1111/j.1461-0248.2000.00185.x.

Eskelinen A, Stark S, Mannisto M. 2009. Links between plant community composition, soil organic matter quality and microbial communities in contrasting tundra habitats. Oecologia 161:113-123 DOI 10.2307/40310119.

Eviner VT. 2004. Plant traits that influence ecosystem processes vary independently among species. Ecology 85:2215-2229 DOI 10.2307/3450286. 
402

403

404

405

406

407

408

409

410

411

412

413

414

415

416

417

418

419

420

421

422

423

424

425

426

Fan JW, Harris W, Zhong HP. 2016. Stoichiometry of leaf nitrogen and phosphorus of grasslands of the Inner Mongolian and Qinghai-Tibet Plateaus in relation to climatic variables and vegetation organization levels. Ecological Research 31: 821-829 DOI 10.1007/s11284016-1392-5.

Groffman PM, Eagan P, Sullivan WM, Lemunyon JL. 1996. Grass species and soil type effects on microbial biomass and activity. Plant and Soil 183:61-67 DOI 10.1007/BF02185565.

Guiz J, Ebeling A, Eisenhauer N, Hacker N, Hertzog L, Oelmann Y, Roscher C, Wagg C, Hillebrand H. 2018. Interspecifc competition alters leaf stoichiometry in 20 grassland species. Oikos 127:903-914 DOI 10.1111/oik.04907.

Guo LZ, Wang K. 2018. Research progress on biology and ecology of Stellera chamaejasme L. Acta Agrestia sinica. 26:525-532 DOI 10.11733/j.issn.1007-0435.2018.03.001 (in Chinese with English abstract).

Güsewell S, Bailey KM, Roem WJ, Bedford BI. 2005. Nutrient limitation and botanical diversity in wetlands: can fertilization raise species richness? Oikos 109:71-80 DOI 10.1111/j.00301299.2005.13587.x.

Güsewell S. 2004. N:P ratios in terrestrial plants: variation and functional significance. New Phytologist 164:243-266 DOI 10.1111/j.1469-8137.2004.01192.x.

Henry HAL, Chiariello NR, Vitousek PM, Mooney HA, Field CB. 2006. Interactive effects of fire, elevated carbon dioxide, nitrogen deposition, and precipitation on a California annual grassland. Ecosystems 9:1066-1075 DOI 10.1007/s10021-005-0077-7.

Hessen DO, Jensen TC, Kyle M, Elser JJ. 2007. RNA responses to N- and P-limitation; reciprocal regulation of stoichiometry and growth rate in Brachionus. Functional Ecology 21:956-962 DOI 10.1111/j.1365-2435.2007.01306.x.

Hou SL, Lü XT, Yin JX, Yang JJ, Hu YY, Wei HW, Zhang ZW, Yang GJ, Liu ZY, Han XG. 2019. The relative contributions of intra- and inter-specific variation in driving community 
427

428

429

430

431

432

433

434

435

436

437

438

439

440

441

442

443

444

445

446

447

448

449

450

stoichiometric responses to nitrogen deposition and mowing in a grassland. Science of the Total Environment 666:887-893 DOI 10.1016/j.scitotenv.2019.02.322.

Hu YY, Sistla S, Wei HW, Zhang ZW, Hou SL, Yang JJ, Wang ZW, Wang JF, Lu XT. 2020. Legacy effects of nitrogen deposition on plant nutrient stoichiometry in a temperate grassland. Plant and soil, 446:503-513 DOI 10.1007/s11104-019-04357-7.

Kagata H, Ohgushi T. 2006. Nitrogen homeostasis in a willow leaf beetle Plasiodera versicolora, is independent of host plant quality. Entomologia Experimentalis et Applicata 118:105-110 DOI 10.1111/j.1570-7458.2006.00377.x.

Kerkhoff AJ, Enquist BJ, Elser JJ, Fagan WF. 2005. Plant allometry, stoichiometry and the temperature-dependence of primary productivity. Global Ecology and Biogeography 14:585-598 DOI 10.1111/j.1466-822x.2005.00187.x.

Klanderud K, Totland O. 2005. The relative importance of neighbours and abiotic environmental conditions for population dynamic parameters of two alpine plant species. Journal of Ecology 93:493-501 DOI 10.1111/j.1365-2745.2005.01000.x.

Korres NE, Norsworthy JK, Brye k, Skinner Jr V, Mauromoustakos A. 2017. Relationships between soil properties and the occurrence of the most agronomically important weed species in the field margins of eastern Arkansas-implications for weed management in field margins. Weed Research 57:159-171 DOI 10.1111/wre.12249.

Lepš J, de Bell F, Šmilauer P, Doležal J. 2011. Community trait response to environment: disentangling species turnover vs intraspecific trait variability effects. Ecography 34:856863 DOI 10.1111/j.1600-0587.2010.06904.x.

Li YY, Dong SK, Liu SL, Wang XX, Wen L, Wu Y. 2014. The interaction between poisonous plants and soil quality in response to grassland degradation in the alpine region of the Qinghai-Tibetan Plateau. Plant Ecology 215:809-819 DOI 10.1007/s11258-014-0333-z. 
451

452

453

454

455

456

457

458

459

460

461

462

463

464

465

466

467

468

469

470

471

472

473

474

475

Liu Y, Long RJ, Yao T. 2004. Research progress on Stellera chamajasme L. in grassland. Pratacultural Science 21:55-61 DOI 10.3969/j.issn.1001-0629.2004.06.017 (in Chinese with English abstract).

Lü XT, Han XG. 2010. Nutrient resorption responses to water and nitrogen amendment in semiarid grassland of Inner Mongolia, China. Plant and Soil 327:481-491 DOI 10.1007/s11104009-0078-y.

Lü XT, Hu YY, Zhang HY, Wei HW, Hou SL, Yang GJ, Liu ZY, Wang XB. 2018. Intraspecific variation drives community-level stoichiometric responses to nitrogen and water enrichment in a temperate steppe. Plant and Soil 423:307-315 DOI 10.1007/s11104017-3519-z.

Lü XT, Kong DL, Pan QM, Simmons ME, Han XG. 2012. Nitrogen and water availability interact to affect leaf stoichiometry in a semi-arid grassland. Oecologia 168:301-310 DOI $10.2307 / 41413934$.

Nielsen SL, Enriquez S, Duarte CM, Sand-Jensen K. 1996. Scaling maximum growth rates across photosynthetic organisms. Functional Ecology 10:167-175 DOI 10.2307/2389840.

Olde Venterink H, Wassen MJ, Verkroost WM, de Ruiter PC. 2003. Species richnessproductivity patterns differ between N-, P-, and K-limited wetlands. Ecology 84:2191-2199 DOI 10.1890/01-0639.

Roem WJ, Berendse F. 2000. Soil acidity and nutrient supply as possible factors determining changes in plant species diversity in grassland and heathland communities. Biological Conservation 92:151-161 DOI 10.1016/S0006-3207(99)00049-X.

Rong QQ, Liu JT, Cai YP, Lu ZH, Zhao ZZ, Yue WC, Xia JB. 2015. Leaf carbon, nitrogen and phosphorus stoichiometry of Tamarix chinensis Lour. in the Laizhou Bay coastal wetland, China. Ecological Engineering 76:57-65 DOI 10.1016/j.ecoleng.2014.03.002.

Sardans J, Peñuelas J, Estiarte M, Prieto P. 2008. Warming and drought alter C and N 
476

477

478

479

480

481

482

483

484

485

486

487

488

489

490

491

492

493

494

495

496

497

498

499

500

concentration, allocation and accumulation in a Mediterranean shrubland. Global Change Biology 14:2304-2316 DOI 10.1111/j.1365-2486.2008.01656.x.

Sardans J, Peñuelas J. 2008. Drought changes nutrient sources, content and stoichiometry in the bryophyte Hypnum cupressiforme Hedw. growing in a Mediterranean forest. Journal of Bryology 30:59-65 DOI 10.1179/174328208X281987.

Sardans J, Rivas-Ubach A, Peñuelas J. 2012. The elemental stoichiometry of aquatic and terrestrial ecosystems and its relationships with organismic lifestyle and ecosystem structure and function: a review and perspectives. Biogeochemistry 111:1-39 DOI 10.1007/s10533011-9640-9.

Scott NA, Saggar S, McIntosh PD. 2001. Biogeochemical impact of Hieracium invasion in New Zealand's grazed tussock grasslands: sustainability implications. Ecological Applications 11:1311-1322 DOI 10.2307/3060922.

Seastedt TR, Vaccaro L. 2001. Plant species richness, productivity, and nitrogen and phosphorus limitations across a snowpack gradient in alpine tundra, Colorado, USA. Arctic Antarctic and Alpine Research 33:100-106 DOI 10.2307/1552283.

Silva DMD, Batalha MA. 2008. Soil-vegetation relationships in cerrados under different fire frequencies. Plant and Soil 311:87-96 DOI 10.1007/s11104-008-9660-y.

Sistla SA, Schimel JP. 2012. Stoichiometric flexibility as a regulator of carbon and nutrient cycling in terrestrial ecosystems under change. New Phytologist 196:68-78 DOI 10.1111/j.1469-8137.2012.04234.x.

Song ML, Chai Q, Li XZ, Yao X, Li CJ, Christensen MJ, Nan ZB. 2015. An asexual Epichloë endophyte modifies the nutrient stoichiometry of wild barley (Hordeum brevisubulatum) under salt stress. Plant and Soil 387:153-165 DOI 10.1007/s11104-014-2289-0.

Song ML, Wang YQ, Bao GS, Yin YL, Liu SC, Yang YW, Yang M, Wang HS. 2018. Effect of different management methods on the community structure and forage quality in Stellera- 
501

502

503

504

505

506

507

508

509

510

511

512

513

514

515

516

517

518

519

520

521

522

523

524

dominated degraded grassland. Pratacultural Science 35:2318-2326 DOI 10.11829/j.issn.1001-0629.2017-0674 (in Chinese with English abstract).

Sterner RW, Elser JJ, Fee EJ, Guildford SJ, Chrzanowski TH. 1997. The light: nutrient ratio in lakes: the balance of energy and materials affects ecosystem structure and process. American Naturalist 150:663-684 DOI 10.1086/286088.

Sterner RW, Elser JJ. 2002. Ecological Stoichiometry: the Biology of Elements from Molecules to the Biosphere. Princeton: Princeton University Press.

Sun G, Luo P, Wu N, Qiu PF, Gao YH, Chen H, Shi FS. 2009. Stellera chamaejasme L. increases soil $\mathrm{N}$ availability, turnover rates and microbial biomass in an alpine meadow ecosystem on the eastern Tibetan Plateau of China. Soil Biology \& Biochemistry 41:86-91 DOI 10.1016/j.soilbio.2008.09.022.

Tessier JT, Raynal DJ. 2003. Use of nitrogen to phosphorus ratios in plant tissues as an indicator of nutrient limitation and nitrogen saturation. Journal of Applied Ecology 40:523-534 DOI 10.1046/j.1365-2664.2003.00820.x

Tibbets TM, Molles MC. 2005. C:N:P stoichiometry of dominant riparian trees and arthropods along the Middle Rio Grande. Freshwater Biology 50:1882-1894 DOI 10.1111/j.13652427.2005.01465.x.

Tilman D. 1982. Resource competition and community structure. Princeton: Princeton University Press.

Tilman D. 1997. Community invisibility, recruitment limitation, and grassland biodiversity. Ecology 78:81-92 DOI 10.2307/2265980.

Van Duren IC, Pegtel DM. 2000. Nutrient limitations in wet, drained and rewetted fen meadows: evaluation of methods and results. Plant and Soil 220: 35-47 DOI 10.1023/A:1004735618905. 
525

526

527

528

529

530

531

532

533

534

535

536

537

538

539

540

541

542

543

544

545

546

547

548

549

Violle C, Enquist BJ, McGill BJ, Jiang L, Albert CH, Hulshof C, Jung V, Messier J. 2012. The return of the variance: intraspecific variability in community ecology. Trends in Ecology \& Evolution 27:244-252 DOI 10.1016/j.tree.2011.11.014.

Vrede T, Dobberfuhl DR, Kooijman S, Elser JJ. 2004. Fundamental connections among organism C:N:P stoichiometry, macromolecular composition, and growth. Ecology 85:12171229 DOI 10.1890/02-0249.

Walter AM, Chritensen S, Simmelsgaard SE. 2002. Spatial correlation between weed species densities and soil properties. Weed Research 42:26-38 DOI 10.1046/j.13653180.2002.00259.x.

Wang HS, Bao GS, Wang YQ, Yin YL, Yang YW, Liu SC, Zhu XL, Song ML. 2018. Effect of different grassland managements strategies on grass productivity in Stellera-dominated degraded grassland. Pratacultural Science 35:2561-2567 DOI 10.11829/j.issn.10010629.2018-0202 (in Chinese with English abstract).

Wang YS, Chua CJ, Maestre FT, Wang G. 2008. On the relevance of facilitation in alpine meadow communities: An experimental assessment with multiple species differing in their ecological optimum. Acta Oecologica - International Journal of Ecology 33:108-113 DOI 10.1016/j.actao.2007.10.002.

Xing F, Song R. 2002. Population distribution pattern and dynamics of poisonous Stellera chamaejasme on grassland. Pratacultural Science 19:16-19 DOI 10.3969/j.issn.10010629.2002.01.004 (in Chinese with English abstract).

Yuan ZY, Chen HYH. 2009. Global-scale patterns of nutrient resorption associated with latitude, temperature and precipitation. Global Ecology and Biogeography 18:11-18 DOI 10.1111/j.1466-8238.2008.00425.x.

Zhang XL, Zhou JH, Guan TY, Cai WT, Jiang LH, Lai LM, Gao NN, Zheng YR. 2019. Spatial variation in leaf nutrient traits of dominant desert riparian plant species in an arid 
$550 \quad$ inland river basin of China. Ecology and Evolution 9:1523-1531 DOI 10.1002/ece3.4877.

551 Zhou SJ, Huang ZJ, A R. 1998. Preliminary study on the allelopathy of Stellera chamaejasme.

552 Grassland of China 4:52-55 DOI 10.3321/j.issn:1673-5021.1998.04.014 (in Chinese with 553 English abstract). 
Figure 1

Effects of Stellera chamaejasme removal on total C, N, and P concentrations (a, c,e), and $C: N, C: P$, and $N: P$ ratios $(b, d, f)$ of different species in an alpine grassland.

E.n: Elymus nutans; P.c: Poa crymophila; K.I: Koeleria litvinowii; F.o: Festuca ovina; S.a: Stipa aliena; K.c: Kobresia capillifolia; K.h: Kobresia humilis; C.a: Carex atrofusc. Asterisk (*) denotes a significant difference $(P<0.05)$ 

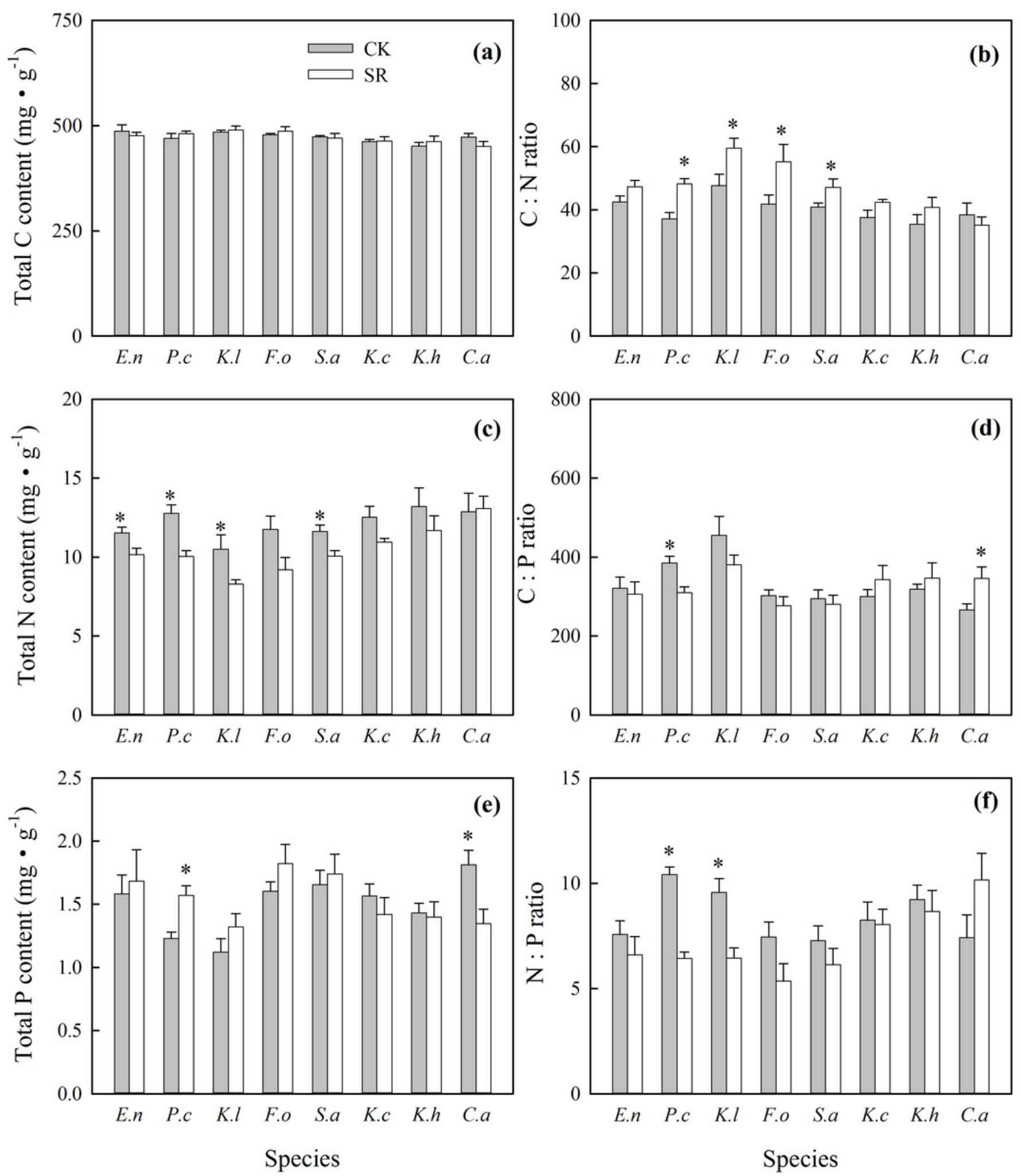
Figure 2

Effects of Stellera chamaejasme removal on total C, N, and P concentrations (a, c,e), and $C: N, C: P$, and $N: P$ ratios $(b, d, f)$ of different functional groups in an alpine grassland.

Asterisk $(*)$ denotes a significant difference $(P<0.05)$. 

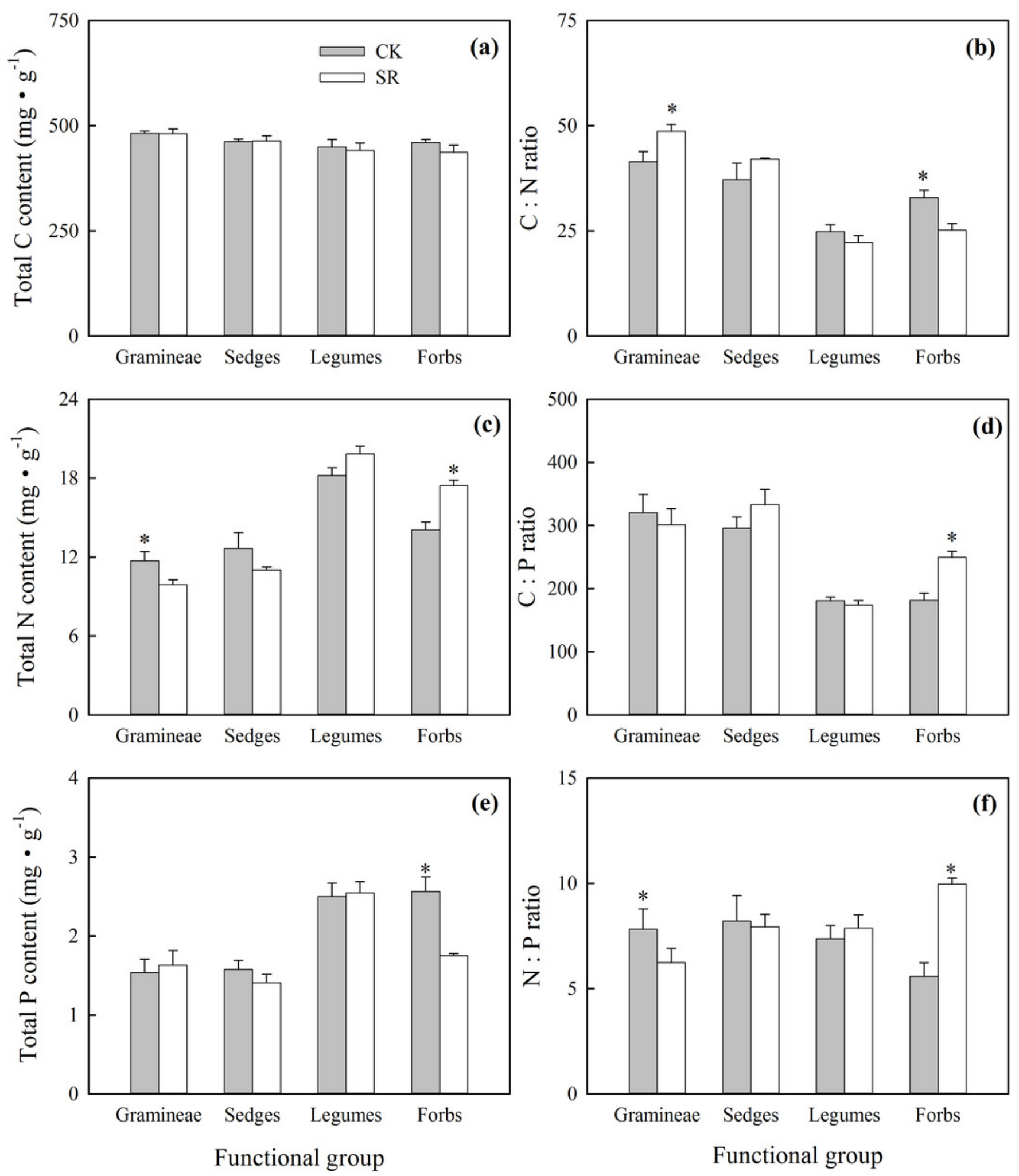
Figure 3

Effects of Stellera chamaejasme removal on total C, N, and P concentrations (a, C, e), and $C: N, C: P$, and $N: P$ ratios $(b, d, f)$ of the plant community in an alpine grassland.

Asterisk $(*)$ denotes a significant difference $(P<0.05)$. 

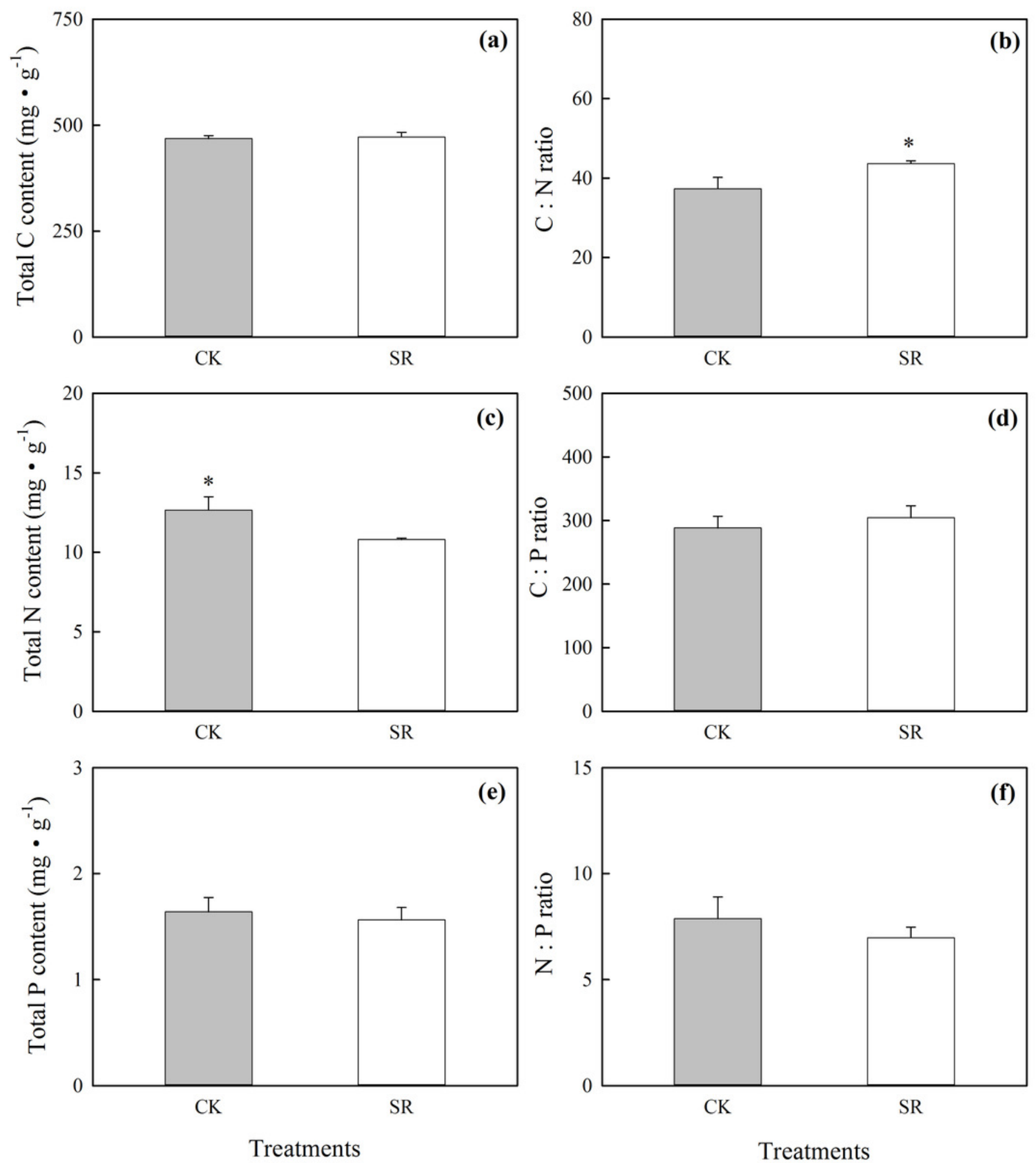


\section{Figure 4}

Principal component analysis (PCA) of the effect of Stellera chamaejasme removal on the stoichiometric traits of different species.

a: Elymus nutans; b: Poa crymophila; c: Koeleria litvinowii; d: Festuca ovina; e: Stipa aliena; f: Kobresia capillifolia; g: Kobresia humilis; h: Carex atrofusc. Green circle (O) and green dotted line represents $C K$, red triangle $(\triangle)$ and red dotted line represents SR. 

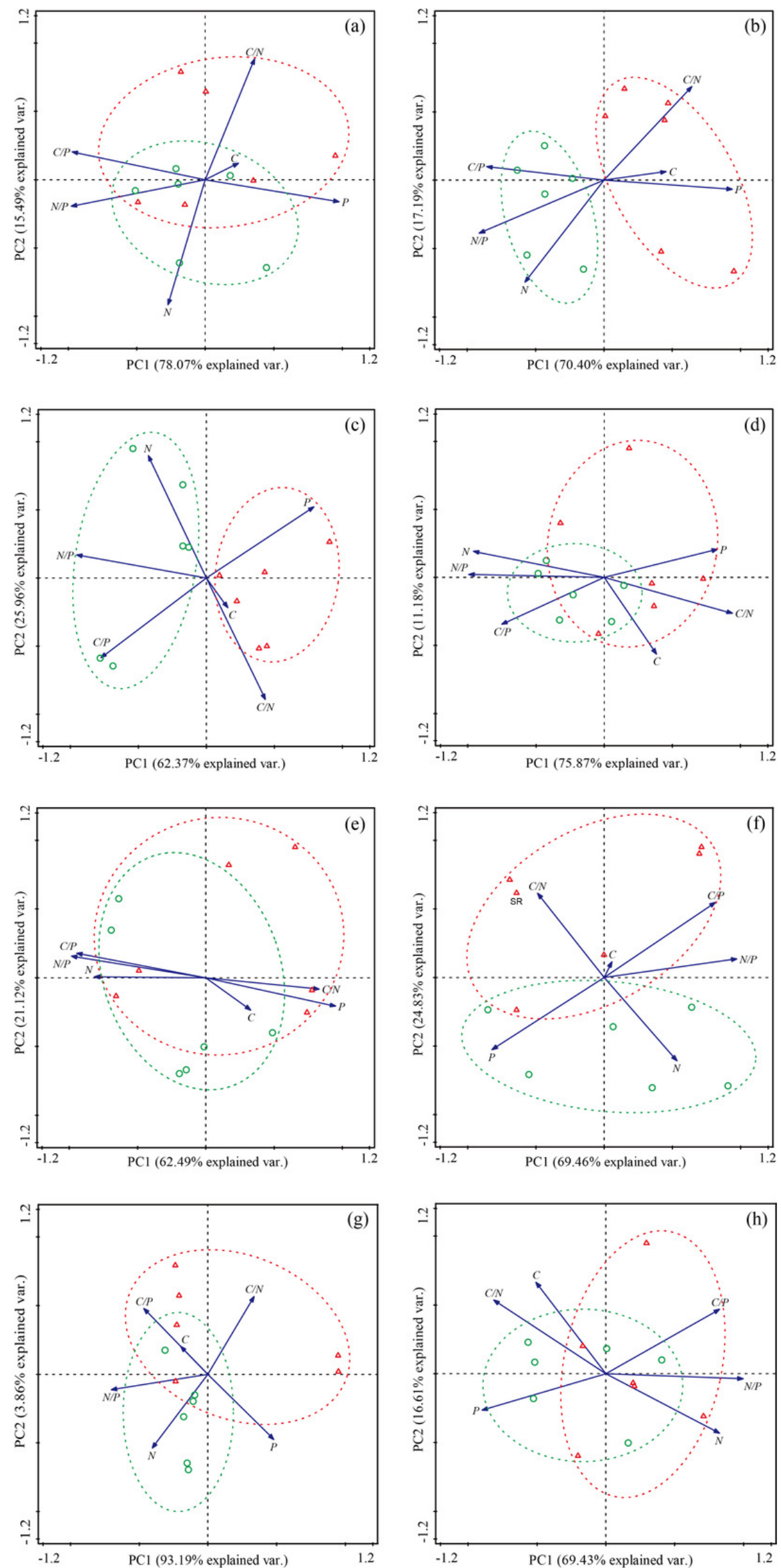

Peer) reviewing PDF | (2019:11:43088:2:0:NEW 21 Apr 2020) 
Figure 5

Principal component analysis (PCA) of the effect of Stellera chamaejasme removal on the stoichiometric traits of different functional groups.

a: Gramineae; b: sedges; c: legumes; d: forbs. Green circle (O) and green dotted line represents $C K$, red triangle $(\triangle)$ and red dotted line represents SR. 

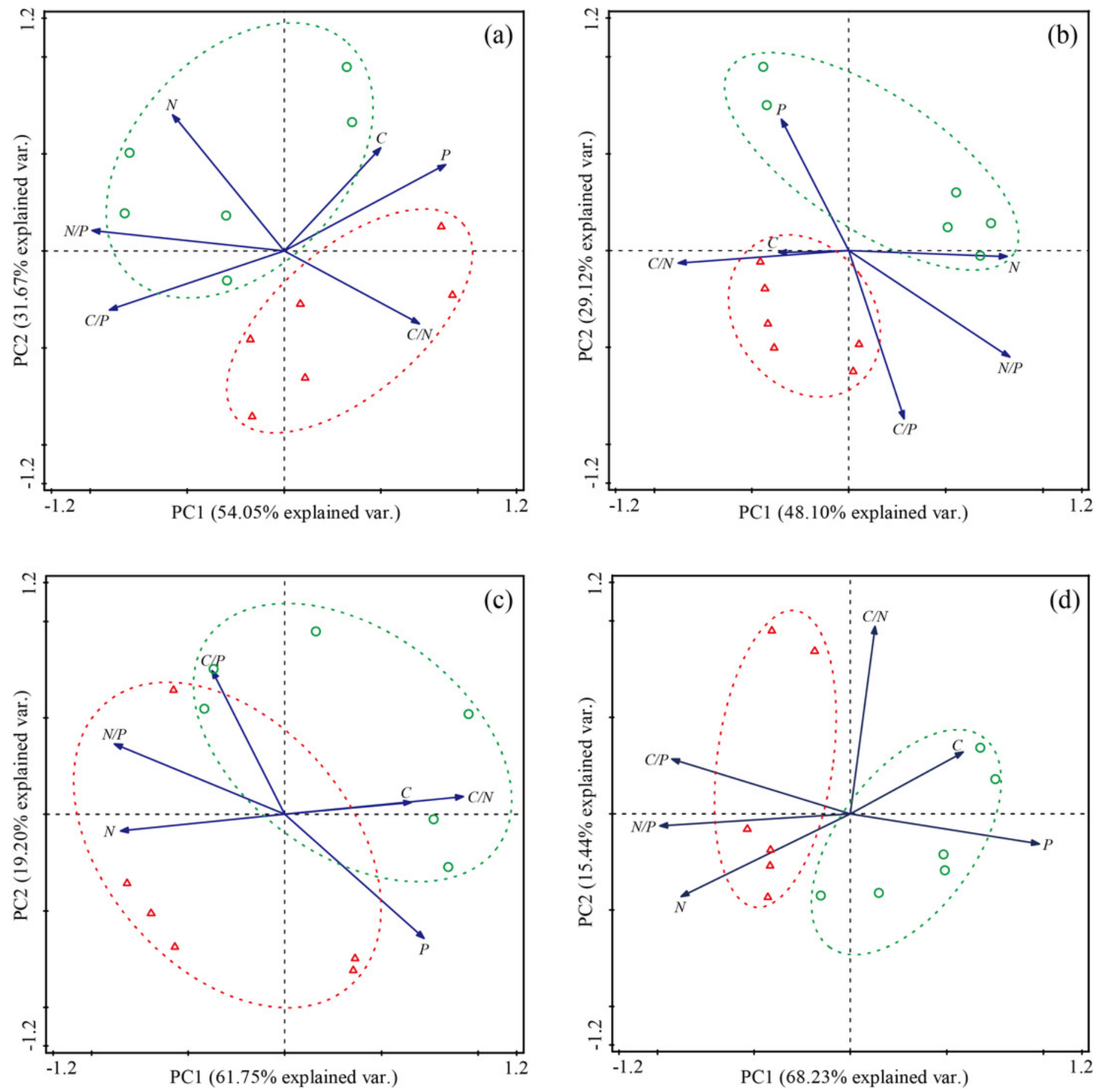
Figure 6

Redundancy analysis (RDA) of the effect of Stellera chamaejasme removal on the stoichiometric traits of the community with soil property.

Green circle $(O)$ and green dotted line represents $C K$, red triangle $(\triangle)$ and red dotted line represents SR. 


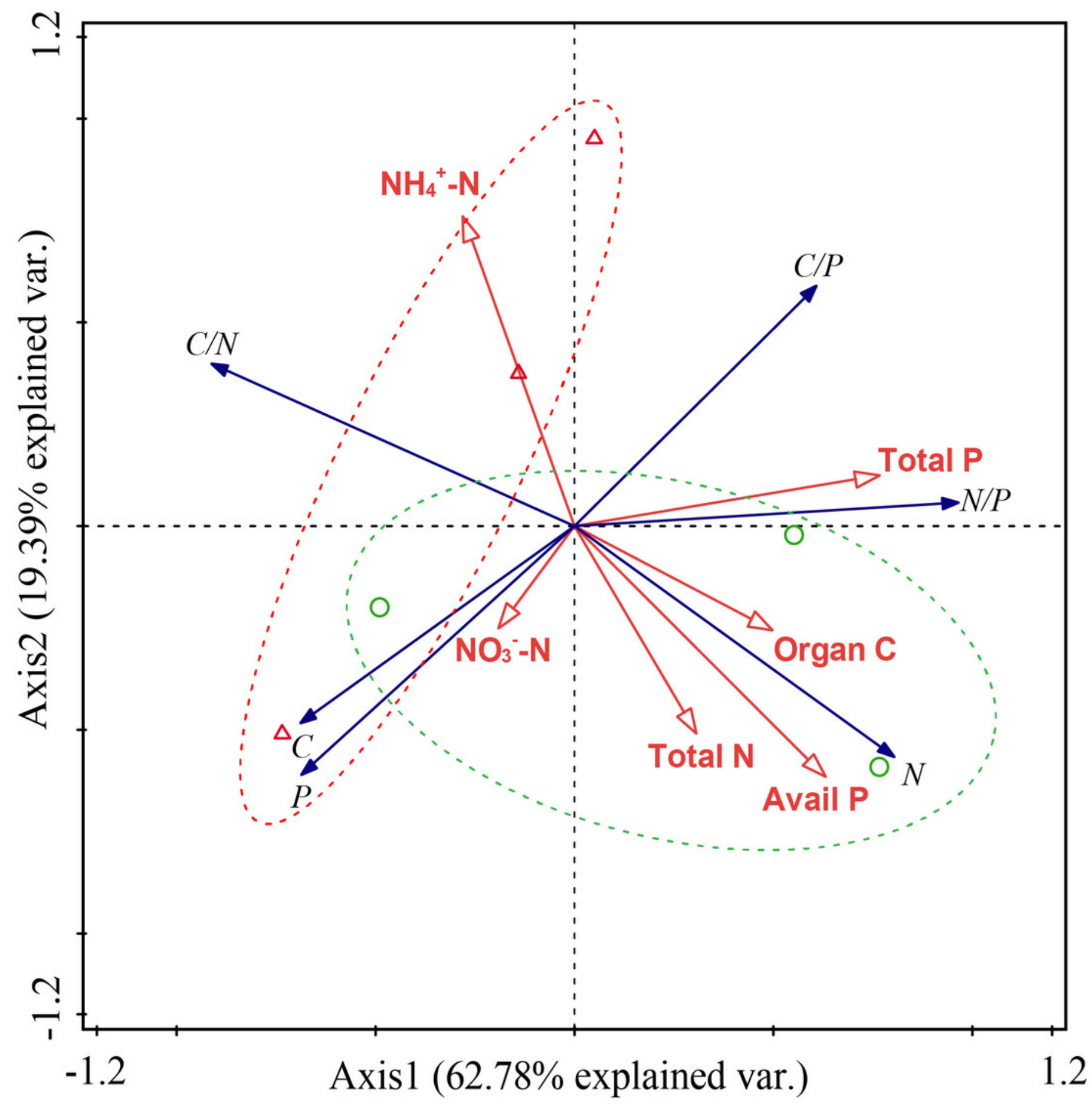




\section{Table $\mathbf{1}$ (on next page)}

Results of a two-way ANOVA for the effects of species (S) and treatments (T) on the content of $C, N$, and $P$ and ratios of $C: N, C: P$, and $N: P$ in an alpine grassland. 
1

\begin{tabular}{|c|c|c|c|c|c|c|c|c|c|c|c|c|c|}
\hline \multirow[b]{2}{*}{ Items } & \multicolumn{3}{|c|}{ C content } & \multicolumn{2}{|c|}{$\mathrm{N}$ content } & \multicolumn{2}{|c|}{$P$ content } & \multicolumn{2}{|c|}{$\mathrm{C}: \mathrm{N}$ ratio } & \multicolumn{2}{|c|}{ C:P ratio } & \multicolumn{2}{|c|}{ N:P ratio } \\
\hline & df & $\mathrm{F}$ & $P$ & $\mathrm{~F}$ & $P$ & F & $P$ & $\mathrm{~F}$ & $P$ & $\mathrm{~F}$ & $P$ & $\mathrm{~F}$ & $P$ \\
\hline Species (S) & 7 & 2.80 & 0.012 & 5.15 & $<0.001$ & 3.61 & 0.002 & 7.50 & $<0.001$ & 4.95 & $<0.001$ & 3.02 & 0.007 \\
\hline Treatments (T) & 1 & 0.00 & 0.985 & 22.17 & $<0.001$ & 0.36 & 0.550 & 22.43 & $<0.001$ & 0.25 & 0.618 & 8.83 & 0.004 \\
\hline $\mathbf{S} \times \mathbf{T}$ & 7 & 0.79 & 0.596 & 0.83 & 0.563 & 2.03 & 0.061 & 1.72 & 0.117 & 2.10 & 0.053 & 3.38 & 0.003 \\
\hline
\end{tabular}

2 


\section{Table 2(on next page)}

Results of a two-way ANOVA for the effects of functional groups (G) and treatments ( $T$ ) on the content of $\mathrm{C}, \mathrm{N}$, and $\mathrm{P}$ and ratios of $\mathrm{C}: \mathrm{N}, \mathrm{C}: \mathrm{P}$, and $\mathrm{N}: \mathrm{P}$ in an alpine grassland. 
1

\begin{tabular}{|c|c|c|c|c|c|c|c|c|c|c|c|c|c|}
\hline \multirow[b]{2}{*}{ Items } & \multirow[b]{2}{*}{$\mathrm{df}$} & \multicolumn{2}{|c|}{$C$ content } & \multicolumn{2}{|c|}{$\mathrm{N}$ content } & \multicolumn{2}{|c|}{$P$ content } & \multicolumn{2}{|c|}{$\mathrm{C}: \mathrm{N}$ ratio } & \multicolumn{2}{|c|}{ C:P ratio } & \multicolumn{2}{|c|}{ N:P ratio } \\
\hline & & $\mathrm{F}$ & $P$ & F & $P$ & $\mathrm{~F}$ & $P$ & $\mathrm{~F}$ & $P$ & $\mathrm{~F}$ & $P$ & $\mathrm{~F}$ & $P$ \\
\hline Groups (G) & 3 & 3.35 & 0.046 & 66.79 & $<0.001$ & 22.01 & $<0.001$ & 43.58 & $<0.001$ & 28.14 & $<0.001$ & 0.68 & 0.577 \\
\hline Treatments & 1 & 0.75 & 0.401 & 0.70 & 0.416 & 4.09 & 0.040 & 0.10 & 0.757 & 2.31 & 0.147 & 1.99 & 0.178 \\
\hline$(\mathrm{T})$ & & & & & & & & & & & & & \\
\hline $\mathbf{G} \times \mathbf{T}$ & 3 & 0.38 & 0.767 & 7.61 & 0.002 & 4.00 & 0.026 & 5.36 & 0.010 & 3.31 & 0.047 & 5.80 & 0.007 \\
\hline
\end{tabular}

2 